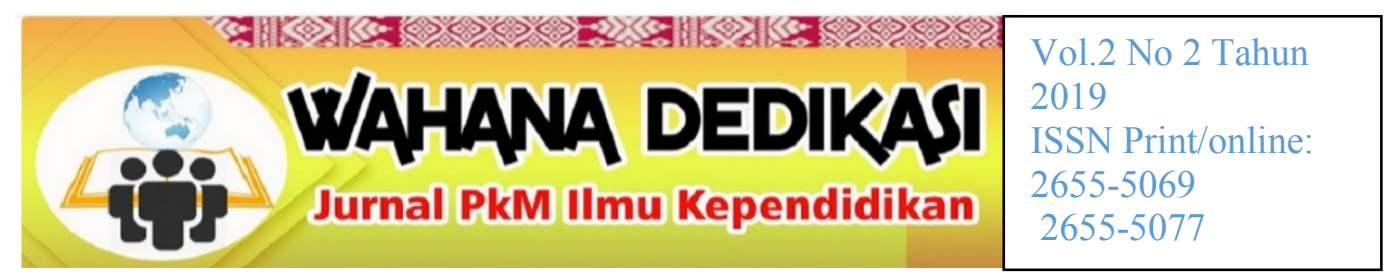

\title{
PELATIHAN TEKNIK, TAKTIK DAN MENTAL MENUJU ATLET BERPRESTASI PADA CABANG BOLAVOLI SMA NEGERI 4 PALEMBANG
}

\author{
Husni Fahritsani ${ }^{1}$, Endie Riyoko ${ }^{2}$, Maya Kurnia ${ }^{3}$, Putri Cicilia Kristina ${ }^{4}$, \\ Perabunita $^{5}$, Daryono ${ }^{6}$, Ferri Hidayat ${ }^{7}$ \\ Universitas PGRI Palembang, Palembang Indonesia ${ }^{1,2,3,4,5,6,7}$ \\ husnifahritsani@univpgri-palembang.ac.id ${ }^{1}$, endieriyoko@univpgri-palembang.ac.id ${ }^{2}$, \\ mayakurnia@univpgri-palembang.ac.id ${ }^{3}$,putrick@univpgri-palembang.ac.id ${ }^{4}$, \\ Perabunita@univpgri-palembang.ac.id ${ }^{5}$, daryono@univpgri-palembang.ac.id ${ }^{6}$, \\ fery6591@gmail.com ${ }^{7}$
}

\begin{abstract}
Abstrak
Didalam dunia pendidikan, olahraga dipandang sebagai salah satu tingkat kecerdasan yang sebenarnya wajib dilatih oleh manusia yaitu kecerdasan kinestetik. Kecerdasan kinestetik merupakan kemampuan manusia didalam melakukan aktifitas yang melibatkan anggota tubuh dengan benar, baik yang didapat secara pribadi maupun yang dipelajari. Kegiatan pelatihan cabor bola voli merupakan wadah yang sangat tepat untuk siswa yang ingin mengembangkan potensi, khususnya dalam bidang olahraga bola voli, diperlukan pengarahan oleh pihak yang bertanggung jawab didalam pendidikan khususnya bidang olahraga, sehingga kegiatan ekstrakurikuler dapat terlaksana dengan efektif.

Kata kuci : Teknik, Taktik, Mental, Bolavoli
\end{abstract}

\begin{abstract}
In the world of education, sport is seen as a level of intelligence that humans must train, namely kinesthetic intelligence. Kinesthetic intelligence is the ability of humans to carry out activities that involve the limbs properly, whether they are obtained personally or learned. Volleyball sports training activities are a very appropriate forum for students who want to develop their potential, especially in the field of volleyball, it requires guidance by those who are responsible for education, especially sports, so that extracurricular activities can be carried out effectively.
\end{abstract}

Key words: Technique, Tactic, Mental, Volleyball

Artikel disetujui tanggal:30-12-2019

Corresponden Author: Husni Fahritsani e-mail: husnifahritsani@univpgri-palembang.ac.id DOI: $h$ ttp://dx.doi.org/10.31851/dedikasi.v2i2.5371 doi 
Husni Fahritsani ${ }^{1}$, Endie Riyoko ${ }^{2}$, Maya Kurnia ${ }^{3}$, Putri Cicilia Kristina ${ }^{4}$,

Perabunita $^{5}$, Daryono ${ }^{6}$, Ferri Hidayat $^{7}$ (2021)

Pelatihan Teknik Taktik dan Mental Menuju Atlet Berprestasi Pada Cabang Bola

Voli SMA Negeri 4 Palembang

\section{WAHANA DEDIKASI}

PENDAHULUAN

Menurut Samsudin

(2013)

pendidikan jasmani adalah suatu proses pembelajaran melalui aktivitas jasmani yang didesain untuk meningkatkan kebugaran jasmani, mengembangkan keterampilan motorik, pengetahuan dan perilaku hidup sehat dan aktif, sikap sportif dan kecerdasan emosi. Lingkungan belajar diatur secara seksama untuk meningkatkan pertumbuhan dan perkembangan seluruh ranah, jasmani, psikomotor, kognitif, dan afektif setiap siswa. Dari penjelasan teori diatas dapat di artikan bahwa pendidikan jasmani merupakan suatu cara yang dilakukan manusia dalam memperoleh pengetahuan olahraga dan mengembangkannya sesuai dengan pengalaman sehingga berdampak pada perubahan pola pikir, prilaku, dan karakter seseorang dalam melakukan aktivitas jasmani kearah yang lebih baik.

Didalam pengembangan keterampilan olahraga melalui pendidikan jasmani terdapat kegiatan yang bisa meningkatkan dan mengembangkan potensi anak dalam meraih prestasi yaitu salah satunya melalui pelatihan yang sesuai dengan program yang telah ditentukan oleh pelatih.

Ricel (2005) Koordisasi merupakan hubungan kerja sama antara susunan syaraf pusat dengan alat gerak saat berkontraksi dalam melakukan gerak tertentu. Koordinasi merupakan hasil perpaduan kinerja dari kualitas otot, tulang, dan persendian dalam menghasilkan satu gerak yang efektif dan efesien, di mana komponen gerak terdiri dari energi, kontraksi otot, syaraf, tulang dan persendian merupakan koordinasi neuromuskuler.

Dari sudut pandang ilmu faal pelatihan atau aktifitas olahraga bertujuan untuk meningkatkan kemampuan fungsional sel, yang dengan sendirinya berarti juga meningkatkan kemampuan fungsional individu (manusia) yg bersangkutan. Pelatihan/aktivitas olahraga harus bersifat fisiologis yaitu: dari sudut pandang sel tidak menyebabkan gangguan Homeostasis yg melebihi batas-batas fisiologis. Perubahan kondisi Homeostasis harus sudah 
Husni Fahritsani ${ }^{1}$, Endie Riyoko ${ }^{2}$, Maya Kurnia ${ }^{3}$, Putri Cicilia Kristina ${ }^{4}$,

Perabunita $^{5}$, Daryono ${ }^{6}$, Ferri Hidayat $^{7}$ (2021)

Pelatihan Teknik Taktik dan Mental Menuju Atlet Berprestasi Pada Cabang Bola

Voli SMA Negeri 4 Palembang

\section{WAHANA DEDIKASI}

pulih dalam waktu tidak lebih dari 24 jam.Pengetahuan dasar tentang apa yang terjadi selama latihan fisik dan bagaimana perubahan itu terjadi sangat penting untuk dimiliki oleh pelatih, pembina, guru olahraga, atlet dan mahasiswa olahraga.

Strategi merupakan rancangan langkah-langkah yang sudah diprogram atau direncanakan, yang akan dilakukan ketika mengikuti sebuah pertandingan. Setiap pemain memiliki peran yang harus dijalankan masing-masing. Meskipun pada dasarnya setiap pemain harus mampu memainkan peran pada setiap posisi, namun masing-masing pemain memiliki spesifikasi tersendiri.

Daya tahan keuatan otot merupakan faktor utama yang mempengaruhi keterampilan atlit dalam permainan bola voli, karena dengan adanya otot yang kuat atlit akan terhindar dari cidera pada saat bermain. Akan halnya dengan kekuatan otot lengan, dalam permainan bola voli berkorelasi dengan keterampilan dalam melakukan servis atas karena pada saat melakukan servis atas, lengan merupakan organ yang sering digunakan, dan di dalam lengan tersebut terdapat otot lengan yang bekerja. Karenanya, tujuan dari latihan pembentukan kekuatann otot lengan adalah untuk meningkatkan daya tahan kekuatan otot lengan pada saat melakukan servis atas.

Ilmu psikologi diterapkan pula ke dalam bidang olahraga yang lalu dikenal sebagai psikologi olahraga. Penerapan psikologi ke dalam bidang olahraga ini adalah untuk membantu agar bakat olahraga yang ada dalam diri seseorang dapat dikembangkan sebaik-baiknya tanpa adanya hambatan dan faktor-faktor yang ada dalam kepribadiannya. Dengan kata lain, tujuan umum dari psikologi olahraga adalah untuk membantu seseorang agar dapat menampilkan prestasi optimal, yang lebih baik dari sebelumnya

Latihan adalah suatu proses yang sistematis dari kerja fisik yang dilakukan berulang-ulang dengan menerapkan prinsip-prinsip latihan. Prinsip Latihan merupakan azas atau ketentuan mendasar dalam proses pembinaan dan latihan yang harus 
Husni Fahritsani ${ }^{1}$, Endie Riyoko ${ }^{2}$, Maya Kurnia ${ }^{3}$, Putri Cicilia Kristina ${ }^{4}$,

Perabunita $^{5}$, Daryono ${ }^{6}$, Ferri Hidayat $^{7}$ (2021)

Pelatihan Teknik Taktik dan Mental Menuju Atlet Berprestasi Pada Cabang Bola

Voli SMA Negeri 4 Palembang

\section{WAHANA DEDIKASI}

dipatuhi terutama oleh pelatih dan atletnya.

Plyometrik adalah salah satu metode untuk mengembangkan eksplosif power, yang merupakan komponen penting dalam pencapaian prestasi sebagian besar atlet. Pemahaman yang terpenting dalam latihan pliometrik adalah, kondisi otot dalam keadaan siap dalam kemampuan otot yang ingin dilatih dan peningkatan harus dilakukan secara bertahap

Hal-hal yang harus diperhatikan dlm latihan pliometrik; Ada pelatih yang mengontrol latihan, Harus sudah latihan kekuatan minimal 3 bulan, Memiliki kekuatan otot yang baik, Melakukan pemanasan sebelum latihan, Memulai latihan dari yang rendah meningkat ke tinggi

\section{BAHAN DAN METODE}

Narasumber dalam kegiatan ini adalah Dosen Pendidikan Jasmani dan kegiatan ini dilaksanakan dilaksanakan pada hari Rabu tanggal 17 Mei 2019 di SMA Negeri 4 Palembang. Dalam memilih metode dan teknik suatu penyuluhan ditentukan oleh banyak hal, Werther (1997) mengatakan bahwa tidak ada satu teknik pelatihan yang paling baik, metode yang paling baik tergantung pada efektivitas biaya, isi program yang diinginkan, prinsipprinsip belajar, fasilitas yang layak, kemampuan dan preference pelatih. Walaupun demikian, pengelola penyuluhan hendaknya mengenal dan memahami semua metode dan teknik dengan cara pelatihan (Hera et al, 2018), sehingga dapat memilih dan menentukan metode dan teknik mana yang paling tepat digunakan sesuai dengan kebutuhan, situasi, dan kondisi yang ada.

Meskipun tidak ada metode yang sempurna, namun dapat dicarikan beberapa alternatif metode yang sesuai dengan karakteristik peserta penyuluhan. Dalam penyelenggaraan pelatihan cabor bola voli pengembangan potensi dan keterampilan olahraga siswa melalui kegiatan olahraga dan bermain (Padilah et al, 2018) yang ada disekolah (ditinjau dari aspek teknik, taktik, fisik dan mental) di SMA Negeri 4 Palembang ini metode 
Husni Fahritsani ${ }^{1}$, Endie Riyoko ${ }^{2}$, Maya Kurnia ${ }^{3}$, Putri Cicilia Kristina ${ }^{4}$,

Perabunita $^{5}$, Daryono ${ }^{6}$, Ferri Hidayat $^{7}$ (2021)

Pelatihan Teknik Taktik dan Mental Menuju Atlet Berprestasi Pada Cabang Bola

Voli SMA Negeri 4 Palembang

\section{WAHANA DEDIKASI}

penyuluhan yang digunakan adalah,

1) lecturing dimana pemateri menjelaskan kepada peserta tentang materi dari pengembangan potensi dan keterampilan olahraga siswa/i melalui kegiatan pelatihan cabor bola voli dalam meraih prestasi, 2) tutorial, yaitu memberikan kesempatan kepada peserta penyuluhan untuk mendiskusikan pengembangan potensi dan keterampilan olahraga siswa/i dalam meraih prestasi melalui kegiatan pelatihan cabor bola voli. Metode yang digunakan ini sesuai dengan persyaratan minimal yang perlu diperhatikan dalam memilih metode pelatihan yaitu (1) sesuai dengan keadaan dan jumlah sasaran, (2) cukup dalam jumlah dan mutu materi, (3) tepat menuju tujuan pada waktunya, (4) amanat hendaknya mudah diterima, dan (5) biaya ringan (Depdikbud, 1985).

\section{HASIL DAN PEMBAHASAN}

Proses kegiatan PKM berlangsung sesuai jadwal. Semua pihak yang telah berupaya sebaik mungkin sesuai kemampuan dan kondisi yang ada. Kegiatan ini dirasakan sangat perlu, namun diharapkan terdapat peningkatan dalam berbagai aspek sehinga pada kegiatan yang akan datang akan menjadi lebih baik dari pada yang terjadi saat ini.

Hasil akhir dari penyelenggaraan kegiatan PKM ini adalah bertambahnya pengetahuan dan pemahaman siswa terhadap manfaat kegiatan pelatihan cabor bola voli dalam meraih prestasi, serta dapat mengaplikasikan kedepannya sehingga dapat menghasilkan atlet berprestasi yang dapat membanggakan terhadap SMA Negeri 4 Palembang khususnya dalam bidang olahraga.

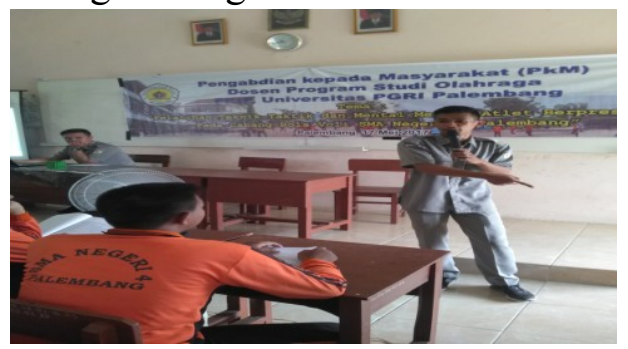

Gambar 1. Penjelasan Materi Taktik

\section{KESIMPULAN \\ Setelah diadakannya pelatihan ini diharapkan kedepannya para siswa:}

\section{8 | Wahana Dedikasi \\ Copyright@Husni Fahritsani}




\section{WAHANA DEDIKASI}

1. Akan lebih teliti dalam mengikuti kegiatan latihan sesuai dengan program yang telah ditetapkan oleh pelatih untuk meraih prestasi dengan mengetahui aspek-aspek pengembangan potensi dan keterampilan olahraga terutama aspek teknik, taktik, fisik dan mental

2. Dapat menetukan cabang olahraga yang tepat untuk diikuti kedepannya sesuai potensi dan keterampilan yang dimiliki.

\section{DAFTAR PUSTAKA}

Depdikbud. 1985. Tugas Guru, Manajemen Kelas, dan Metoda Mengajar. Bandung: Kanwil Provinsi Jawa Barat.

Hera, T., Rochayati, R., Diah, N., Elvandari, E., \& Nurdin, N. (2018). Pelatihan tari lenggang patah sembilan dalam konteks pementasan tari pada siswa-siswi smp negeri $\quad 30 \quad$ kota palembang. Wahana dedikasi, 1(2).

Padilah, P., Utami, F., Jaya, M. P. S., Sinaga, S. I., Novianti, R., \& Noverina, R. (2018). Sosialisasi Inovasi Media Pembelajaran Permainan Tunas Integritas Untuk Perkembangan Anak Usia
Dini di PAUD Kasih Bunda Yuliani Kec. Ilir Barat I. Wahana Dedikasi, 1(2).

Ricel, P. (2005). Intimate Relationship, Marriage and Family. $\quad 4^{\text {th }} \quad$ edition. Callifornia: Mayfield Publishing Co

Samsudin. 2013. Kurikulum Pendidikan Jasmani Dan Olahraga. Jakarta: UNJ Press

Werther Jr. W. B. E., Davis, Keith. (1997). Human Resource and Personal Management Fifth Edition. Mc. Graw Hill. Inc. 